NOTE

\title{
Larvae of Contracaecum sp. among inshore fish species of southwestern Australia
}

\author{
A. J. Lymbery*, R. G. Doupé, M. A. Munshi, T. Wong \\ Division of Veterinary and Biomedical Sciences, Murdoch University, Western Australia 6150, Australia
}

\begin{abstract}
Larval nematode infections were investigated in 236 fish from 17 estuarine and near-shore species in southwestern Australia. Larvae of the genus Contracaecum were found in 4 species of fish (Acanthopagrus butcheri, Sillaginodes punctata, Mugil cephalus and Aldrichetta forsteri). The prevalence and intensity of infection was highest in the 2 species of mullet: $81 \%$ infected and $9.8 \pm 1.5$ larvae fish $^{-1}$ for M. cephalus; $100 \%$ and $12.7 \pm 3.7$ larvae fish $^{-1}$ for A. forsteri. There was no evidence of post-mortem migration of worms from the visceral organs to the musculature of the fish.
\end{abstract}

KEY WORDS: Nematodes - Inshore fish - Anisakidae • Contracaecum

Resale or republication not permitted without written consent of the publisher

Nematodes of the family Anisakidae are commonly found in marine fish, and the most widespread genera, Anisakis, Pseudoterranova and Contracaecum, have similar life cycles. Adult parasites live in the stomach or small intestine of piscivorous marine mammals and birds. Eggs shed in the faeces and larvae are ingested by an invertebrate (usually crustacean) intermediate or paratenic host. Various species of fish and cephalopods may also act either as a second intermediate host, or as a paratenic host (Anderson 1992, Køie \& Fagerholm 1995, Køie et al. 1995). Anisakid nematodes are widely distributed, and their prevalence among a variety of fish species can be very high. Wharton et al. (1999), for example, found Anisakis larvae in $82 \%$ of 100 red gurnard Chelidonichthys kumu, in $84 \%$ of 100 tarakihi Nemadactylus macropterus and in $100 \%$ of 36 barracouta Thyristes atun in New Zealand waters.

There have been very few studies of anisakids in fish in Australia. Cannon $(1977 \mathrm{a}, \mathrm{b})$ found 9 larval morphotypes of the genera Anisakis, Contracaecum, Terranova and Thynnascaris in 47 species of marine fish

*E-mail: alymbery@central.murdoch.edu.au from Queensland, northeast Australia. As far as we are aware, no surveys have been conducted on the southern or western coasts of the country. The aim of this study was to survey the prevalence of anisakid larvae in marine fish in southwestern Australia. The survey was not comprehensive, and we concentrated on a number of inshore fish species that are commonly targeted by both recreational fishers and commercial operations for the local market.

Materials and methods. In all, 236 fish representing 17 species of estuarine and near-shore fish were sampled from routine demographic surveys conducted by Fisheries Western Australia and from a Perth metropolitan recreational fishing club. Whole fish were either immediately frozen or placed on ice prior to inspection. Fillets were thinly sliced and examined under white light, and the visceral organs, mesenteries, and peritoneum were disrupted before examination under white light. Larvae were counted, their location recorded, and stored in $70 \%$ ethanol. Worms were then immersed in lactophenol for $48 \mathrm{~h}$, mounted, and examined microscopically for taxonomic identification. Larval nematode prevalence (percentage of fish infected), and mean intensity (mean number of parasites per infected fish) were calculated where specific sample sizes exceeded 10 fish.

Results and discussion. In contrast to previous studies of marine fish in eastern Australia and New Zealand (Cannon 1977a,b, Wharton et al. 1999), we found only 1 genus of anisakid: Contracaecum (Ascaridida; Anisakidae). This may reflect the bias in our sampling towards estuarine and inshore habitats, where fish are principally bottom dwelling, benthic feeding species. Morphologically, all the isolates of Contracaecum were identical to Contracaecum type I (thick bodied third stage larvae, 19.0 to $26.8 \mathrm{~mm}$ in length, sharply pointed tail) described by Cannon (1977b). The species-level taxonomy of Contracaecum is confused 
and just beginning to be addressed by molecular genetic techniques (Nadler et al. 2000, Zhu et al. 2000). We are collaborating in molecular studies to determine the taxonomic affiliations of anisakid nematodes in Australia. These studies should provide specific identification and life cycle confirmation of the Contracaecum isolates described here; in the meantime, type specimens have been lodged with Dr. L. Cannon at the Museum of Queensland (Accession Number G218789).

Sample sizes exceeded 10 individual fish for only 8 of the 17 species of fish examined. Larvae of Contracaecum sp. were found in 4 of these species (black bream, King George whiting, sea mullet and yelloweyed mullet). The prevalence and intensity of Contracaecum infections was greatest in the 2 species of mullet (Table 1). Parasites were found on and in the liver (79\% in sea mullet, $93 \%$ in yellow-eyed mullet), on the surface of the dorsal aorta (19.3\% in sea mullet, $6.6 \%$ in yellow-eyed mullet), on the surface of the stomach ( $1.5 \%$ in sea mullet, $0.4 \%$ in yellow-eyed mullet), and in the mesenteries and peritoneum $(0.2 \%$ in sea mullet, $0 \%$ in yellow-eyed mullet).

The high prevalence of Contracaecum infection in species of mullet, and the large number of worms in infected fish, may have implications for the health of the fish and also for the potential definitive and accidental hosts that eat infected fish. Our observations are that the most commonly infected organ in fish was the liver, and parasitised livers showed gross morphological changes. Previous studies have found reductions in weight and liver fat content in fish infected with Contracaecum (Acha \& Szyfres 1987). A number of worms were also found adjacent to the dorsal aorta in infected fish, and invasion of the cardiac region has been associated with the death of young fish (Acha \& Szyfres 1987).

Members of the genus Contracaecum mature in piscivorous birds or mammals (Anderson 1992). For the species found in this study, the definitive host is likely to be one or more species of piscivorous birds, possibly of the order Pelicaniformes (Cannon 1977b). Species of
Contracaecum have been reported from a number of species of cormorants Phalacrocorax spp. and pelicans Pelecanus spp. in Australia, Europe and North America (Johnston \& Mawson 1941, Huizinga 1971, Pyrovetsi \& Papazaharidou 1995). Many studies have suggested that heavy infections of Contracaecum in birds may cause haemorrhage and ulcers in the stomach, leading to illness and death, especially when associated with adverse environmental conditions or other stress factors (e.g. Oglesby 1960, Huizinga 1971, Pyrovetsi \& Papazaharidou 1995, Fagerholm et al. 1996, Kuiken et al. 1999).

Mullet are a common and popular fish caught in recreational activities in Western Australia and are also fished commercially, with between 1 and 2 tonnes marketed locally in Perth each year. Although much less invasive than nematodes of the genera Anisakis and Pseudoterranova, larvae of Contracaecum species have been shown experimentally to be infective to mammals (Vidal-Martinez et al. 1994), and have occasionally been identified in people (see Beaver et al. 1984). Their preferred occurrence in visceral organs, rather than the flesh of fish, limits their zoonotic potential. We found no worms in the flesh of infected fish. Wharton et al. (1999) suggested that if fish are not frozen or filleted soon after capture, then larval nematodes may migrate into the flesh. Post-mortem migration was investigated by obtaining 20 sea mullet from the Perth wholesale fish market $6 \mathrm{~h}$ after capture. Whole dead fish were maintained at $4^{\circ} \mathrm{C}$ for $60 \mathrm{~h}$ and then dismantled for inspection; 75 worms were found and all were in the visceral organs, mesenteries, and peritoneum, with no evidence of post-mortem migration into fish flesh. Post-mortem migration has been described for larvae of Anisakis spp. in northern hemisphere herring Clupea harengus and mackerel Scomber scombrus (Smith \& Wootten 1975, Smith 1984), but other studies have not been able to demonstrate the phenomenon in these or other fish species (Khalil 1969, Cattan \& Carvajal 1984, Roepstorff et al. 1993).

Table 1. Prevalence (\% infected) and intensity (mean number of larvae/fish $\pm \mathrm{SE}$ ) of infections of inshore fish species in southwestern Australia with larvae of the nematode Contracaecum

\begin{tabular}{|llccc|}
\hline Common name & Scientific name & Number examined & Prevalence & Intensity \\
\hline Australian herring & Arripris georgianus & 29 & 0 & 0 \\
Black bream & Acanthopagrus butcheri & 26 & 4 & 1 \\
King George whiting & Sillaginodes punctata & 32 & 6 & 1.5 \\
Samson fish & Seriola hippos & 13 & 0 & 0 \\
Sand whiting & Sillago sp. & 20 & 81 & 0 \\
Sea mullet & Mugil cephalus & 58 & 100 & $9.8 \pm 1.5$ \\
Yellow-eyed mullet & Aldrichetta forsteri & 19 & 0 & $12.7 \pm 3.7$ \\
Yellow-finned whiting & Sillago schomburgkii & 13 & & 0 \\
\hline
\end{tabular}


Acknowledgements. We appreciate the cooperation of Fisheries Western Australia and members of the Marmion Angling and Aquatic Club. J. Brown, J. Carlton, J. Dias, G. Sarre, N. Smith and L. Thomas helped with collections. R. Hobbs, I. Beveridge and L. Cannon very kindly provided taxonomic advice.

\section{LITERATURE CITED}

Acha PN, Szyfres B (1987) Zoonoses and communicable diseases common to man and animals, 2nd edn. Pan American Health Organisation, Washington, DC

Anderson RC (1992) Nematode parasites of vertebrates. CAB International, Wallingford

Beaver PC, Jung CR, Cupp EW (1984) Clinical parasitology, 9th edn. Lea \& Febiger, PA

Cannon LRG (1977a) Some ecological relationships of larval ascaridoids from south-eastern Queensland marine fishes. Int J Parasitol 7:227-232

Cannon LRG (1977b) Some larval ascaridoids from southeastern Queensland marine fishes. Int $\mathrm{J}$ Parasitol 7: 233-243

Cattan PE, Carvajal J (1984) A study of the migration of larval Anisakis simplex (Nematoda: Ascaridida) in the Chilean hake, Merluccius gayi (Guichenot). J Fish Biol 24:649-654

Fagerholm HP, Overstreet RM, Humphrey-Smith I (1996) Contracaecum magnipapillatum (Nematoda, Ascaridoidea)-resurrection and pathogenic effect of a common parasite from the proventriculus of Anous minutus from the Great Barrier Reef, with a note on C. variegatum. Helminthologia 33:195-207

Huizinga HW (1971) Contracaeciasis in pelicaniform birds. J Wildl Dis 7:198-204

Johnston TH, Mawson PM (1941) Ascaroid nematodes from Australian birds. Trans R Soc SA 65:110-115

Khalil LF (1969) Larval nematodes in the herring (Clupea harengus) from British coastal waters and adjacent territories. J Mar Biol Assoc UK 49:641-659

Køie M, Fagerholm H (1995) The life cycle of Contracaecum osculatum (Rudolphi, 1802) sensu stricto (Nematoda,

Editorial responsibility: Wolfgang Körting,

Hannover, Germany
Ascaridoida, Anisakidae) in view of experimental infections. Parasitol Res 81:481-489

Køie M, Berland B, Burt MDB (1995) Development to thirdstage larvae occurs in the eggs of Anisakis simplex and Pseudoterranova decipiens (Nematoda, Ascaridoidea, Anisakidae). Can J Fish Aquat Sci 52(Suppl 1):134-139

Kuiken T, Leighton FA, Wobeser G, Wagner B (1999) Causes of morbidity and mortality and their effect on reproductive success in double-crested cormorants from Saskatchewan. J Wildl Dis 35:331-346

Nadler SA, D'Amelio S, Fagerholm HP, Berland B, Paggi L (2000) Phylogenetic relationships among species of Contracaecum Railliet \& Henry, 1912 and Phosascaris Host, 1932 (Nematoda: Ascaridoidea) based on nuclear rDNA sequence data. Parasitology 121:455-463

Oglesby LC (1960) Heavy nematode infestation of white pelican. Auk 77:354

Pyrovetsi M, Papazaharidou M (1995) Mortality factors of Dalmatian pelicans (Pelecanus crispus) wintering in Macedonia, Greece. Environ Conserv 22:345-351

Roepstorff A, Karl H, Bloemsa B, Huss HH (1993) Catch handling and the possible migration of Anisakis larva in herring, Clupea harengus. J Food Prot 56:783-787

Smith JW (1984) The abundance of Anisakis simplex L3 in the body cavity and flesh of marine teleosts. Int J Parasitol 14 491-495

Smith JW, Wootten R (1975) Experimental studies on the migration of Anisakis sp. larvae (Nematoda: Ascaridida) into the flesh of herring, Clupea harengus L. Int J Parasitol. 5:133-136

Vidal-Martinez VM, Osorio-Sarabia D, Overstreet RM (1994) Experimental infection of Contracaecum multipapillatum (Nematoda: Anisakidae) from Mexico in the domestic cat. J Parasitol 80:576-579

Wharton DA, Hassall ML, Aalders O (1999) Anisakis (Nematoda) in some New Zealand inshore fish. NZ J Mar Freshw Res 33:643-648

Zhu XQ, D'Amelio S, Paggi L, Gasser RB (2000) Assessing sequence variation in the internal transcribed spacers of ribosomal DNA within and among members of the Contracaecum osculatum complex (Nematoda: Ascaridoidea: Anisakidae). Parasitol Res 86:677-683

Submitted: February 21, 2001; Accepted: April 30, 2002 Proofs received from author(s): July 31, 2002 